\title{
Comparative Study between Direct and Indirect Treatment with Cold Atmospheric Plasma on In Vitro and In Vivo Models of Wound Healing
}

\author{
Constance Duchesne, ${ }^{\mathrm{a}, \mathrm{b},{ }^{*}}$ Nadira Frescaline, ${ }^{\mathrm{a}, \mathrm{b}}$ Jean-Jacques Lataillade, ${ }^{\mathrm{b}}$ \& \\ Antoine Rousseau ${ }^{\mathrm{a}, *}$ \\ aLPP, Ecole Polytechnique, UPMC, Université Paris Sud 11, CNRS, Palaiseau, France; ' Institut \\ de Recherche Biomédicale des Armées, INSERM UMRS-MD 1197, Centre de Transfusion \\ Sanguine des Armées, 92141 Clamart, France \\ *Address all correspondence to: Constance Duchesne, LPP, Ecole Polytechnique, UPMC, Université Paris Sud 11, \\ CNRS, Palaiseau, France; Tel.: +0169335878, E-mail: constance.duchesne@lpp.polytechnique.fr; or Dr. Antoine \\ Rousseau, LPP, Ecole Polytechnique, UPMC, Université Paris Sud 11, CNRS, Palaiseau, France; Tel.: +0169335963, \\ E-mail: antoine.rousseau@lpp.polytechnique.fr
}

\begin{abstract}
Cold-atmospheric plasma (CAP) produces a mixture of molecular, ionic, and radical species as well as electric field visible and ultraviolet lights. Biological effects of CAP and its therapeutic potential have been studied in disciplines such as dermatology, oncology, and dentistry. This study investigates both in vitro and in vivo effects of direct and indirect plasma treatment and their influences on wound healing. The effect of plasma treatment on cellular viability, migration, and proliferation are studied using keratinocytes, fibroblasts, and endothelial cells. Plasma is generated in a helium jet using an alternating-current $50-\mathrm{Hz}$ power supply at $32 \mathrm{kV}$ and $90 \mathrm{~mW}$. Results show that 1-min direct CAP treatment stimulates skin cell migration; however, cellular proliferation remains unchanged. Treatment $>3$ min leads to cell death. Using the same treatment parameters, notably exposure time, indirect treatment using a plasma-activated medium fails to stimulate cellular migration. A murine model of full-thickness excisional wound healing is used to study the effect of CAP on wound closure. In vivo studies demonstrate that both direct and indirect treatment do not affect acute wound closure in mice. Taken together, these results suggest that direct plasma treatment with homemade plasma devices has the potential to positively influence wound healing, but optimum parameters and suitable wound models must be identified and validated.
\end{abstract}

KEY WORDS: cold atmospheric plasma, plasma-activated media, skin cells, cellular viability, cellular migration, acute wounds, wound healing

\section{INTRODUCTION}

Skin, the largest human organ, is composed of three layers: epidermis, dermis, and subcutaneous fat tissue. Cutaneous injury repair involves complex biological processes that are classically divided into three stages: inflammation, new tissue formation, and remodeling. Inflammation occurs directly after tissue damage. Immune cells are recruited to remove nonviable tissue and prevent infection. Homeostasis is achieved with the formation of a platelet plug followed by a fibrin matrix. New tissue formation, the second stage of wound repair, is characterized by cellular proliferation and migration. Keratinocytes 
in the epidermis, fibroblasts in the dermis, and endothelial cells that occur with the formation of new blood vessels (angiogenesis) proliferate and migrate into the wound bed. Later during this stage, fibroblasts differentiate into myofibroblasts (contractile cells that assist in wound contracture). The third stage of wound healing is remodeling. Once the injury is repaired, cells that have accumulated in the wound bed exit or undergo apoptosis, and the extracellular matrix is remodeled. ${ }^{1}$ Most frequently, skin injury results in an acute skin wound that rapidly heals but in some cases results in a benign scar. In the case of deep injuries, such as burns and chronic wounds, healing is often delayed, resulting in significant morbidity and mortality. Each year in the United States, 70,000 burn injuries and 600,000 to 1.5 million venous leg ulcer wounds occur. These injuries cost nearly $\$ 20$ billion/yr. ${ }^{2}$ Furthermore, these numbers are expected to rise due to the aging population. Thus, cutaneous wound healing is a major burden for health-care systems worldwide. During past decades, little improvement has been shown in preventing morbidity and mortality caused by skin wounds. In the case of chronic wounds, the best available treatment achieves only a 50\% healing rate, and healing is mainly temporary. ${ }^{3}$ Thus, new innovative treatment and wound management are needed to positively impact patient healing time, comfort, and medical-care costs.

Cold atmospheric plasmas (CAPs) are weakly ionized gases that are produced by electric discharges. They contain ground-state and excited atoms, radicals and molecules, charged particles, and ultraviolet radiation. ${ }^{4}$ CAPs can be generated at atmospheric pressure in ambient air and do not exceed body temperature. Hence, CAP can be used as treatment in the human body to generate short- and long-lived reactive oxygen and nitrogen species (ROS and RNS) and electric field that is in contact with living tissues.

The application of CAP in biomedical research has increased during the last ten years in several domains such as infection-related disease in dermatology, ${ }^{5-8}$ skin wounds, ${ }^{9-11}$ blood coagulation, ${ }^{12}$ cancer treatment, ${ }^{13-15}$ inactivation of several microorganisms, ${ }^{16}$ decontamination of medical devices and surfaces in hospitals, ${ }^{17,18}$ and cosmetics. ${ }^{12}$ Positive results have already been obtained in these fields, in vitro and in vivo, and some clinical trials have been conducted that produced successful treatment of different types of skin injuries including acute wounds, ${ }^{11}$ burns, ${ }^{19}$ skin infection, ${ }^{20}$ chronic leg ulcers,${ }^{21}$ eczema, ${ }^{22}$ and psoriasis. ${ }^{23}$ Other clinical trials have proven that plasma treatment is safe and causes no toxic effect or pain. ${ }^{24,25}$

Most in vitro studies show that effects of CAP on mammalian cells generally depend on treatment time and energy applied. ${ }^{26,27}$ Optimum treatment time depends on plasma sources and other parameters such as voltage or gas flow. Different studies have shown that plasma can affect skin cells by modulating viability, migration, and proliferation. ${ }^{28,29}$ These effects were observed for a short treatment duration, corresponding to small energies of approximately a few joules per squared centimeters. ${ }^{10,30,31}$ Most of the literature regarding the effect of CAP on skin cells focuses on one or two cell types: keratinocytes and fibroblasts. ${ }^{10,28,32}$ To our knowledge, only Arndt et al. have studied the effects of the device MicroPlaSter $\beta$ (Adtec Healthcare; Middlesex, UK) on keratinocytes, fibroblasts, and endothelial cells in three complementary articles..$^{28,31,33}$ Here, we study three skin cell types to investigate the effect of a homemade plasma device on cellular response and biological reaction. 
The main mechanisms that describe the interaction between plasma and skin cells are still under investigation. However, reactive chemical species produced by plasma are major candidates, especially ROS and reactive oxygen and nitrogen species (RONS). RONS, such as nitric oxide $\left(\mathrm{NO}^{\circ}\right)$, hydroxyl radical $\left(\mathrm{OH}^{\circ}\right)$, hydrogen peroxide $\left(\mathrm{H}_{2} \mathrm{O}_{2}\right)$, and ozone, are actually well known to have an important role in animal and plant biochemistry. ${ }^{34-36}$ ROS are involved in oxidative stress stimuli and can have a double role in living systems. Thus, they can cause cellular damage or dysfunction if their concentrations are too high, but at lower concentrations, they serve as cellular signals and can positively impact wound healing. $\mathrm{NO}^{\circ}$, for example, is a molecule known to stimulate angiogenesis, cell proliferation, inflammation, and wound remodeling. ${ }^{37,38}$

In the case of biological applications, two types of plasma treatment are usually used: direct and indirect. In the case of direct treatment, cells or tissue are directly treated with plasma sources. With indirect treatment, a biological medium is treated by plasma and then applied to the biological target. This is called plasma-activated media (PAM). In this case, the treated biological target receives only long-life reactive species that is produced by the interaction between plasma and treated liquid. This differs from direct treatment, in which short-life species, ultraviolet radiation, charged particles, and electromagnetic fields can also play a part. Very few studies have been performed to study the effect of PAM on skin cells, and to our knowledge, the current study is the first to conduct a comparison between PAM and direct plasma treatment, both in vitro and in vivo.

In this study, in vitro experiments were first performed on three cell lines: keratinocytes, endothelial cells, and fibroblasts. We determined an optimum treatment time to ensure that skin cells remained viable to promote their migration in vitro. Three different types of treatment were compared: direct treatment of cells in media, indirect treatment using freshly prepared PAM, and treatment using chemicals. Chemicals used were long-life RONS that were produced by plasma in liquids and included $\mathrm{H}_{2} \mathrm{O}_{2}, \mathrm{NO}_{2}^{-}$, and $\mathrm{NO}_{3}^{-}$. We also conducted an in vivo trial using a model of murine full-thickness excisional wound healing to study the influence of direct or indirect plasma on wound healing rate.

\section{MATERIALS AND METHODS}

\section{A. Plasma Source and Power Measurement}

We used a homemade plasma jet as the plasma source (Fig. 1), which was constructed using three-dimensional (3D)-printing technology. The apparatus was made of polylactic acid (PLA)-graphite (resistivity $\rho=44 \mathrm{~m} \Omega . \mathrm{m}$ ) (Proto-Pasta; Vancouver, WA), and a needle electrode was placed inside. For the gas, helium (Air Liquide; Paris, France) flowed in a capillary in the middle of the 3D-printed structure, using a total flow rate of $500 \mathrm{sccm}$ (0.5 standard L/min [sLm]). The capillary was $60 \mathrm{~mm}$ high (distance between the height of the voltage electrode and gas outlet), with a diameter of $3 \mathrm{~mm}$. The helium capillary was separated from the electrode, and $1 \mathrm{~mm}$ of PLA (eSun; Shenzhen, China) formed

Volume 8, Issue 4, 2018 

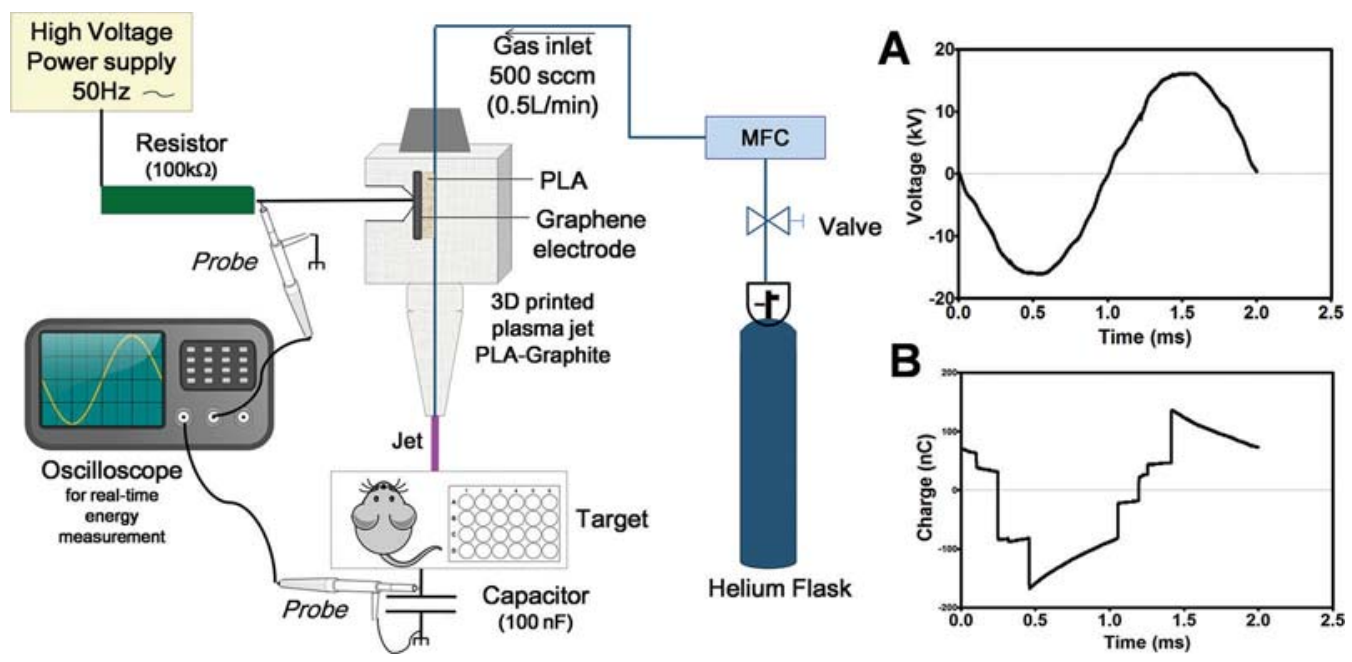

FIG. 1: Schematic diagram of CAP generating system. (A) Voltage of the power supply measured by a high-voltage probe; (B) charge measured at the terminal of the measuring capacitor $(105 \mathrm{nF}$ ). Exposed to the plasma source is $2 \mathrm{~mL}$ of PBS (diameter, 4; height, $60 \mathrm{~mm}$; energy, 1), with helium flow at $500 \mathrm{sccm}$, height at $5 \mathrm{~mm}$, and peak-to-peak voltage at $32 \mathrm{kV}$. MFC, mass flow controller; PLA, polylactic acid.

a dielectric barrier. The 15-mm PLA ensured electrical insulation around the PLA-graphene electrode. We used a $50-\mathrm{Hz}$ homemade generator with a sinusoidal waveform to provide high voltage set to $32 \mathrm{kV}$ peak to peak.

We measured the power delivered by the plasma in real time, acquiring voltage measurements using an oscilloscope (Rohde \& Schwarz; Munich, Germany). A capacitor connected in series with the target of the plasma jet allowed us to measure the amount of charge that was carried by each microdischarge. In vitro, aluminum was placed under the treated plate to ensure the connection with the capacitor. In vivo, we placed a selfadhesive electrode WhiteSensor (Ambu; Ballerup, Denmark) near the treated area to ensure a link to the capacitor for power measurement.

\section{B. Measurement of Chemical Concentration}

\section{1. $\mathrm{H}_{2} \mathrm{O}_{2}$}

Hydrogen peroxide concentrated in phosphate-buffered saline (PBS) was determined using a colorimetric reaction using Amplex ${ }^{\circledR}$ Red (10-acetyl-3,7-dihydroxyphenoxazine; Sigma-Aldrich; St. Louis, MO). We treated $2 \mathrm{~mL}$ of media in a 24-well plate (Corning; Ithaca, NY) with plasma, using a gap of $5 \mathrm{~mm}$ between liquid surface and CAP source. We mixed $50 \mu \mathrm{L}$ of the sample with $50 \mu \mathrm{L}$ of $100 \mu \mathrm{M}$ Amplex Red and $50 \mu \mathrm{L}$ of $0.5-\mathrm{U} / \mathrm{mL}$ horseradish peroxidase. Absorbance was measured after 20 min using a microplate reader 
(Labsystems; Vantaa, Finland) at $540 \mathrm{~nm}$. Results were expressed in micrometers. Based on the standard curve, we obtained the $\mathrm{H}_{2} \mathrm{O}_{2}$ concentration in treated the PBS.

\section{2. $\mathrm{NO}_{2}^{-}$and $\mathrm{NO}_{3}^{-}$}

We determined total nitrite/nitrate concentration in the treated PBS using a colorimetric assay kit (Sigma-Aldrich). Absorbance was measured using a microplate reader (Labsystems) at $540 \mathrm{~nm}$, and results were expressed in micrometers.

\section{NO}

NO in the media was measured using 2,3-diaminonaphtalène (Sigma-Aldrich). Together, they produced 2,3-naphthotriazole, a fluorescent molecule that can be detected in a very low nanomolar concentration range.

\section{Cells Culture and Treatment Conditions}

Adherent cells were cultured in confluent monolayers. The endothelials that we used included dermal, blood, microvascular (MV), endothelial, and neonatal cells (HMVEC; Lonza; Verviers, Belgium). These were grown in endothelial-cell growth medium(EGM), comprised of 99\% EGM-2 MV Bulletkit (Lonza) and 1\% antibiotics (Gibco; Paisley, PA). Primary fibroblasts and $\mathrm{HaCaT}$ were grown in high-glucose Dulbecco's Modified Eagle Medium that was supplemented with $1 \%$ antibiotic Antimycotic $1 \times($ Gibco Life Technologies; Paisley, PA) and 10\% HyClone FetalClone II serum (GE Healthcare Life Sciences; Pittsburgh, PA). We used primary fibroblasts from three different donors, including human dermal fibroblasts that were isolated from patients undergoing mammoplasty and/or abdominoplasty. Patients were free from drugs such as steroids and immunosuppressive medications that might interfere with dermal matrix formation. Informed consent was obtained and the study protocol conformed to ethical guidelines of the 1975 Declaration of Helsinki, as reflected by approval of the relevant Human Research Ethics Committee. Human primary dermal fibroblasts were isolated using an explant technique.

Cells were seeded in a 24-well plate, and wells were filled with $2 \mathrm{~mL}$ of fresh media. The distance between liquid surface and plasma jet nozzle was fixed at $5 \mathrm{~mm}$. Voltage was set to $32 \mathrm{kV}$ during treatment. Treatment was direct (cells were treated in media) or indirect using PAM. In this case, media were treated under the same conditions and immediately poured onto cells that were treated for 1,2, or 3 min with plasma jet. Cells were treated once per day during 24 or $48 \mathrm{~h}$, and all experiments were performed in triplicate.

\section{Viability Assay}

We examined cell viability using a LIVE/DEAD Cell Viability kit for mammalian cells (Thermofisher Scientific; Waltham, MA). Cells were seeded in the 24-well plate, grown

Volume 8, Issue 4, 2018 
to $70 \%$ confluence, treated in $2 \mathrm{~mL}$ of fresh media once (T0) or twice (T0 and T24 h), and viability was analyzed at 24 and $48 \mathrm{~h}$, respectively, after the first treatment.

After 24 or $48 \mathrm{~h}$, cells were washed before assay to remove or dilute serum esterase activity that might generally be present in serum-supplemented growth media (serum esterase could cause increased extracellular fluorescence by hydrolyzing Calcein-AM [ThermoFisher Scientific]). Adherent cells were gently washed with 500-1000 volumes of Dulbecco's PBS (S-PBS). After this, $150 \mu \mathrm{L}$ of a fresh solution of Calcein (1:1000; $1 \mu \mathrm{M})$ and ethidium $(1: 1000 ; 1 \mathrm{M})$ were added to each well. After $30 \mathrm{~min}$ of incubation at room temperature, labeled cells were directly observed under a fluorescence microscope (Leica Microsystems GMBH; Wetzlar, Germany). Dead cells appeared as to be red, because ethidium enters cells with membrane damage. Cells with normal intracellular esterase activity appeared to be green.

\section{E. Proliferation Assay}

The effect of plasma on proliferation and viability of cells was tested using Cell Proliferation Reagent WST-1 (Sigma-Aldrich). The amount of yellow formazan dye generated by the cells is known to be directly proportional to the number of viable cells, because this salt is changed into yellow dye by the mitochondrial nicotinamide adenine dinucleotide phosphate-dehydrogenase activity of living cells. Adherent cells were suspended at 2000 cells/well in $100 \mu \mathrm{L}$ of media in a 96-well plate. At 24 or $48 \mathrm{~h}$ after plasma treatment, we added $10 \mu \mathrm{L}$ of cell proliferation reagent WST-1 (0501594400; Sigma-Aldrich) per well and incubated the plates for $1 \mathrm{~h}$ in a humidified atmosphere of $37^{\circ} \mathrm{C}$ and $5 \% \mathrm{CO}_{2}$. We measured sample absorbance using a microplate reader (Labsystems) at $450 \mathrm{~nm}$, with a $600-\mathrm{nm}$ reference.

\section{F. Scratch Assay or Wound Healing Assay}

Cell migration was assessed using a scratch assay (also known as a wound healing assay). Cells were seeded in a 24 -well plate $(250,000$ cells/well) and allowed to grow to $90 \%$ confluence. Then, a scratch was mechanically performed in the middle of the wells using a 1-mL pipette tip. The long axial of the tip was always perpendicular to the bottom of the well. The resulting gap distance was equal to the outer diameter of the tip end. After scratching, the well was washed with fresh medium to remove detached cells. Cells were then treated in $2 \mathrm{~mL}$ of fresh media once (T24 h) or twice (T0 and T24 h). The first treatment was performed immediately after the scratch. Three types of treatments were processed for this experiment: direct, indirect (PAM), and treatment with $\mathrm{H}_{2} \mathrm{O}_{2}, \mathrm{NO}_{2}^{-}$, and $\mathrm{NO}_{3}^{-}$at a concentration equivalent to 1 min of plasma treatment. Photos of the scratch were acquired at 0,24 , and $48 \mathrm{~h}$ after first scratch. Gap distance was evaluated using the ImageJ computer program (National Institutes of Health and Laboratory for Optical and Computation Instrumentation; Bethesda, MD). Results were represented as mean percentage of the original wound at $\mathrm{T} 0$. 


\section{G. Wound Induction and Treatment}

We used female BALB/c mice that were between 6 and 10 wk of age (18-22 g) (Janvier Labs; Le Genest-Sainte-Isle, France). All animal experiments were approved by the relevant animal ethics committee (permit no. APAFIS\#9118-2017030217494790 v2). Mice were anesthetized using 4\% isofluorane and hair was removed from the dorsum using hair clippers and depilatory cream. A full-thickness wound measuring $6 \mathrm{~mm}$ in diameter was induced on the dorsum surface using a biopsy punch (Dominique Dutscher; Brumath, France). Experiments were carried out using six mice per group.

Experimentation was divided into two phases. The first used indirect treatment with an injection of $200 \mu \mathrm{L}$ sterile PBS treated with plasma for $1 \mathrm{~min}(2 \mathrm{~mL}$ PBS in a 24-well plate, 4 joules) using a microfine needle (30 gauge; $0.30 * 8 \mathrm{~m}$ ). Four $50-\mu \mathrm{L}$ injections were delivered all around the wound. Control mice were treated with an injection of PBS to create the same stress situation for all animals. Untreated mice were included in another control group.

In the second case, mice wounds were treated directly with plasma for 10 or $30 \mathrm{~s}$ during the first day only or every $2 \mathrm{~d}$ (three treatments in $7 \mathrm{~d}$ ). Plasma operating at 500 sccm was projected onto the wound surface from a distance of 7-10 $\mathrm{mm}$. Voltage was set at $24 \mathrm{kV}$ during treatment. No heating of tissue was detected or measured during treatment. Measurements were made using an infrared camera (Testo; Lenzkirch, Germany). During treatment, mice were under anesthesia after inhaling isofluorane. All treatments were carried out at room temperature, using atmospheric pressure according to the same protocol. No treatment was performed on the mice from the control group. Digital photographs of wounds were taken at 2, 4, 6, and $7 \mathrm{~d}$ after wounds were received. At day 7 , mice were euthanized and wounds excised for histological analysis.

\section{H. Histological Analysis}

Extracted samples of skin were fixed in $10 \%$ buffered formalin for $24 \mathrm{~h}$ and placed in $70 \%$ ethanol until they were processed for histology. Tissue samples were stained using hematoxylin and eosin (H\&E). Stained samples were then imaged using a scanner equipped with a $20 \times$ objective lens (Leica Microsystems GMBH).

\section{Statistical Analysis}

All graphs and statistical analyses were performed using Prism 5 software (GraphPad; San Diego, CA). All data were expressed as mean values $+/-$ standard error of the mean (SEM). To compare two groups, we used the Mann-Whitney U test for unrelated samples. In the case of fibroblasts, data were paired (donor effects) and a nonparametric Wilcoxon paired test was used. To compare more than two groups, we used a nonparametric Kruskal-Wallis test. A Dunn test was used as the posttest among groups. A $p$ value of $<0.05$ was considered as statistically significant.

Volume 8, Issue 4, 2018 


\section{RESULTS}

\section{A. Deposited Plasma Energy and Production of Reactive Species for In Vitro Experiments}

In the following experiments, working parameters were set as follows: $V=32 \mathrm{kV}$, helium mass flow $=500 \mathrm{sccm}$, and distance between liquid surface and plasma source $=$ $5 \mathrm{~mm}$. Three different treatment times were studied: 1, 2, and $3 \mathrm{~min}$. Measured power was set to between 70 and $100 \mathrm{~mW}$.

Table 1 shows deposited energy values and production of $\mathrm{H}_{2} \mathrm{O}_{2}, \mathrm{NO}_{2}^{-}$, and $\mathrm{NO}_{3}^{-}$in 2 $\mathrm{mL}$ of treated PBS. Levels of NO in media could not be measured. Thus, it was assumed that the NO that was produced by the plasma was below a detectable range (5 nM) of the method. The plasma jet operated at ambient pressure and temperature and generated the following species: $\mathrm{H}_{2} \mathrm{O}_{2}, \mathrm{NO}_{2}^{-}$, and $\mathrm{NO}_{3}^{-}$. Concentrations of these molecules in the PBS were proportional to treatment time when other plasma parameters remained fixed.

\section{B. Toxicity and Proliferation In Vitro}

First, we tested toxicity of our plasma device treatment at 1, 2, or 3 min on keratinocytes, endothelials, and primary fibroblasts. The two tests that were performed to check cytotoxic effects of plasma treatment were a LIVE/DEAD assay that yielded a percentage of dead cells and a WST-1 assay that enabled quantification of cell proliferation and viability. Cells were treated every $24 \mathrm{~h}$ and percentage of mortality was measured at 24 or $48 \mathrm{~h}$ after the first treatment. Indirect treatment from $30 \mathrm{~s}$ to 3 min showed no toxic effects on skin cells or did not significantly affect proliferation during the observation period of up to $48 \mathrm{~h}$ (Figs. 2-5). Direct treatment, like indirect treatment, showed no effect on cell proliferation (Fig. 5). However, direct treatment of $3 \mathrm{~min}$ led to an increased percentage of dead cells (Figs. 2-4). Endothelial cells were the most fragile among the three studied cells, with

TABLE 1: Energy calculated from power measurement and concentration of $\mathrm{H}_{2} \mathrm{O}_{2}, \mathrm{NO}_{2}^{-}$, and $\mathrm{NO}_{3}^{-}$in $2 \mathrm{~mL}$ of media treated by CAP in a $24-$ well plate

\begin{tabular}{|l|c|c|c|c|c|}
\hline \multirow{2}{*}{} & \multicolumn{3}{|c|}{ 24-Well plate } & \multicolumn{2}{c|}{ Mice } \\
\cline { 2 - 6 } & $\mathbf{1}$ min & $\mathbf{2}$ min & $\mathbf{3 ~ m i n}$ & $\mathbf{1 0 ~ s}$ & $\mathbf{3 0} \mathbf{~}$ \\
\hline Energy $(\mathrm{J})$ & 4.3 & 9.1 & 13 & 0.05 & 0.2 \\
\hline Energy density $\left(\mathrm{J} / \mathrm{cm}^{3}\right)$ & 2.2 & 4.5 & 6.5 & - & - \\
\hline $\mathrm{H}_{2} \mathrm{O}_{2}(\mu \mathrm{M})$ & $8+/-0.01$ & $14+/-0.5$ & $23+/-0.7$ & - & - \\
\hline $\mathrm{NO}_{2}^{-}(\mu \mathrm{M})$ & $1.2+/-0.29$ & $2+/-0.25$ & $2.6+/-0.26$ & - & - \\
\hline $\mathrm{NO}_{3}^{-}(\mu \mathrm{M})$ & $0.5+/-0.12$ & $0.65+/-0.09$ & $1.4+/-0.19$ & - & - \\
\hline
\end{tabular}

Energy is represented for two different biological targets: Mice and $2 \mathrm{~mL}$ of media in a 24-well plate. Data were measured with the following set of parameters: Helium flow, $500 \mathrm{sccm}$; height, $5 \mathrm{~mm}$; and peak-to-peak voltage, $32 \mathrm{kV}$ as a function of treatment time. Each value is the average of the minimum of three different treatments with SEM. 

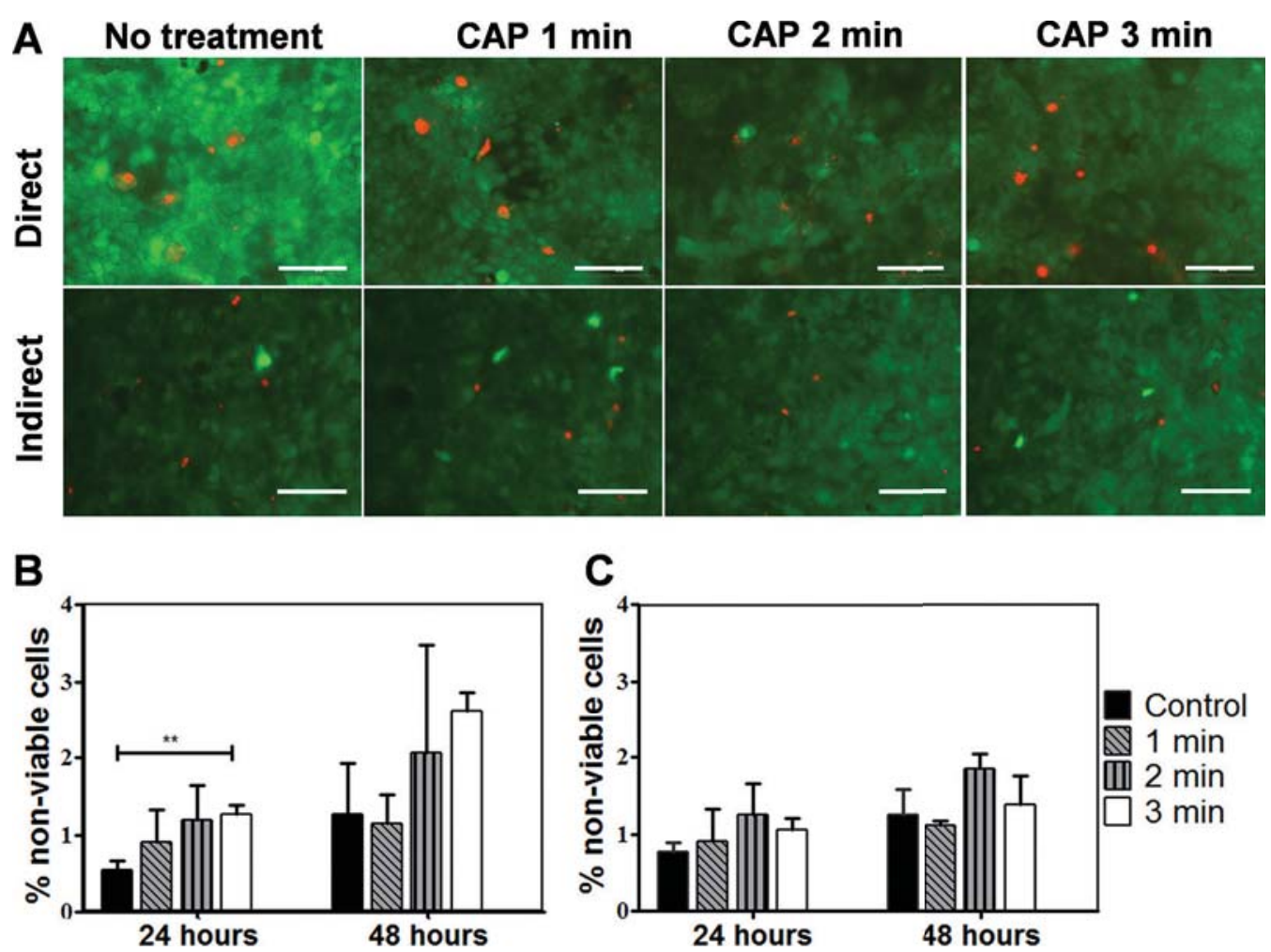

FIG. 2: LIVE/DEAD ${ }^{\mathrm{TM}}$ viability assay of $\mathrm{HaCaT}$ cells treated by CAP. (A) Optical fluorescent images of $\mathrm{HaCaT}$ at $48 \mathrm{~h}$ after plasma treatment. Cells were stained with Calcein-AM (green or darker surrounding) and ethidium (red or brighter embedded points). (B) Quantitative analysis of LIVE/DEAD cell viability at 24 and $48 \mathrm{~h}$ after direct CAP treatments. (C) Quantitative analysis of LIVE/DEAD cell viability at 24 and $48 \mathrm{~h}$ after PAM treatments. Error bars represent the SEM of three measurements. Scale, $100 \mu \mathrm{m}$. CAP, Cold-atmospheric plasma.

increased cell mortality of $70 \%$ (Fig. 3). For cells, direct treatment was more damaging than indirect treatment. Thus, long-lived species in PAM, such as $\mathrm{H}_{2} \mathrm{O}_{2}$, had no effect on cell viability. To verify this assumption, cell viability was measured after treatment using $\mathrm{H}_{2} \mathrm{O}_{2}$ at up to $150 \mu \mathrm{M}$, equivalent to 10 min of plasma treatment. Treatment with $\mathrm{H}_{2} \mathrm{O}_{2}$ did not induce cell toxicity. Therefore, plasma toxicity on cells after treatment that was longer than 3 min may be due to oxidative stress from short-lived ROS or electromagnetic field.

\section{Migration In Vitro}

Migration of keratinocytes, fibroblasts, and endothelial cells in the wound bed is a key process that promotes timely wound closure. The effect of direct and indirect CAP treatment on migration of the three skin cell types was studied using a scratch assay (Fig. 6). Cells treated directly by plasma during an optimized duration migrated more quickly

Volume 8, Issue 4, 2018 

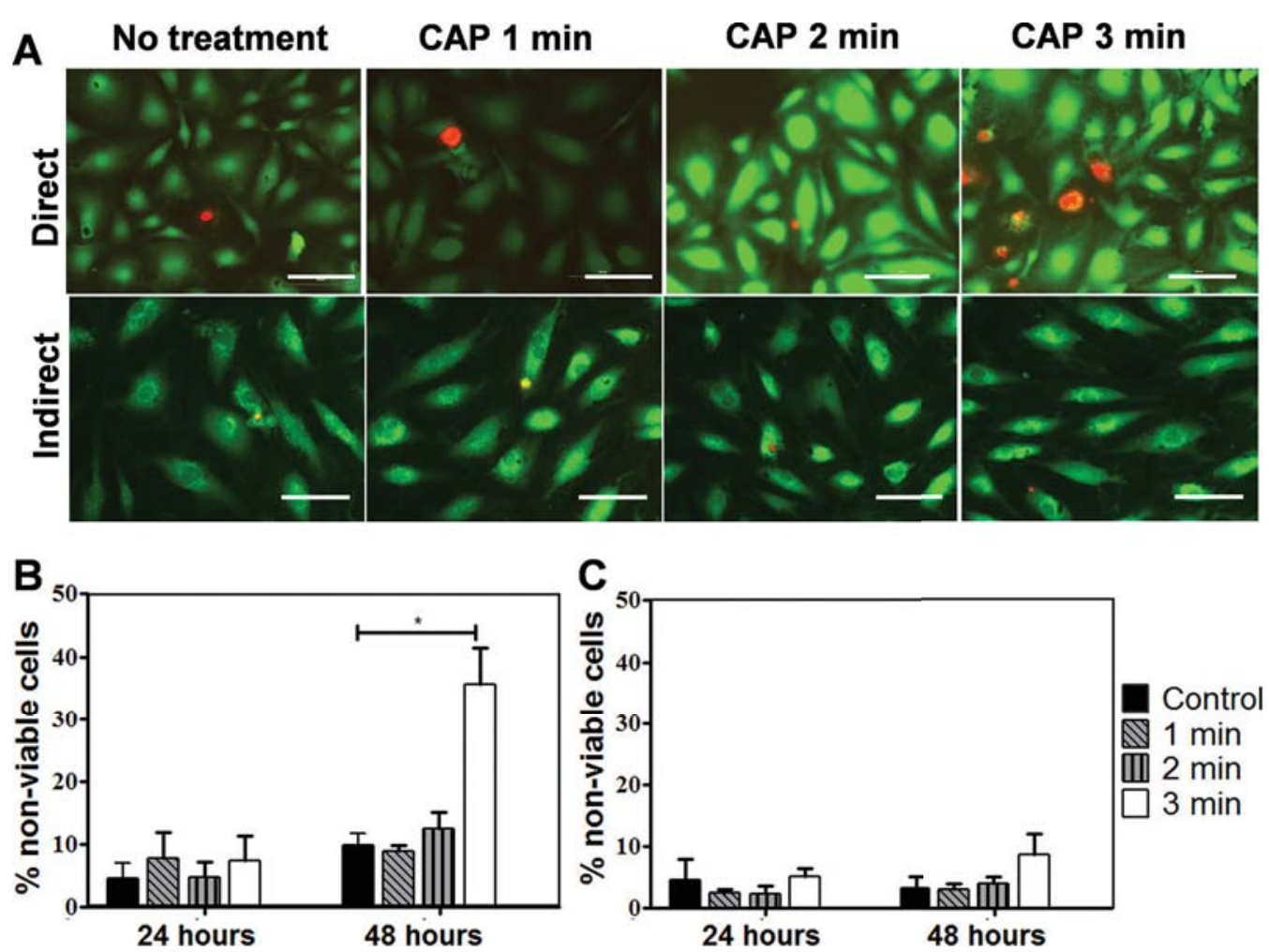

FIG. 3: LIVE/DEAD viability assay of endothelial cells treated by CAP. (A) Optical fluorescent images of primary fibroblasts at $48 \mathrm{~h}$ after plasma treatment. Cells were stained with Calcein-AM (green or darker surrounding) and ethidium (red or brighter embedded points). (B) Quantitative analysis of LIVE/DEAD cell viability at 24 and $48 \mathrm{~h}$ after direct CAP treatments. (C) Quantitative analysis of LIVE/DEAD cell viability at 24 and $48 \mathrm{~h}$ after PAM treatments. Error bars represent the SEM of three measurements. Scale, $100 \mu \mathrm{m}$. CAP, Cold-atmospheric plasma.

[Fig. 7(A),(D),(G)]. Thus, with keratinocytes and endothelial cells, 1 and 2 min of treatment led to quicker scratch closure at 24 and $48 \mathrm{~h}$ after the scratch. At $24 \mathrm{~h}$, the surface of the scratch in treated keratinocyte wells was $70 \%$ smaller than that of the control. For endothelial cells after $24 \mathrm{~h}$, the surface of the scratch in the treated wells was $\sim 50 \%$ smaller when compared to the control [Fig. 7(D)]. For primary fibroblasts, only direct treatments for $1 \mathrm{~min}$ had a significant positive effect on migration, with a reduction in scratch surface of $25 \%$ [Fig. 7(G)]. Contrary to direct treatment, PAM (indirect treatment) had no effect on migration of all cell types, regardless of treatment time [Fig. 7(B),(E),(H)]. Thus, the set of long-lived species comprising PAM did not induce cell migration in this range of concentration. However, each species may have had a positive or negative effect, resulting in autocompensation. To determine whether this occurred, the same scratch assay for treating cells was performed using $\mathrm{H}_{2} \mathrm{O}_{2}, \mathrm{NO}_{2}^{-}$, and $\mathrm{NO}_{3}^{-}$. The concentrations that were used were equivalent to what were produced for 1 min of 

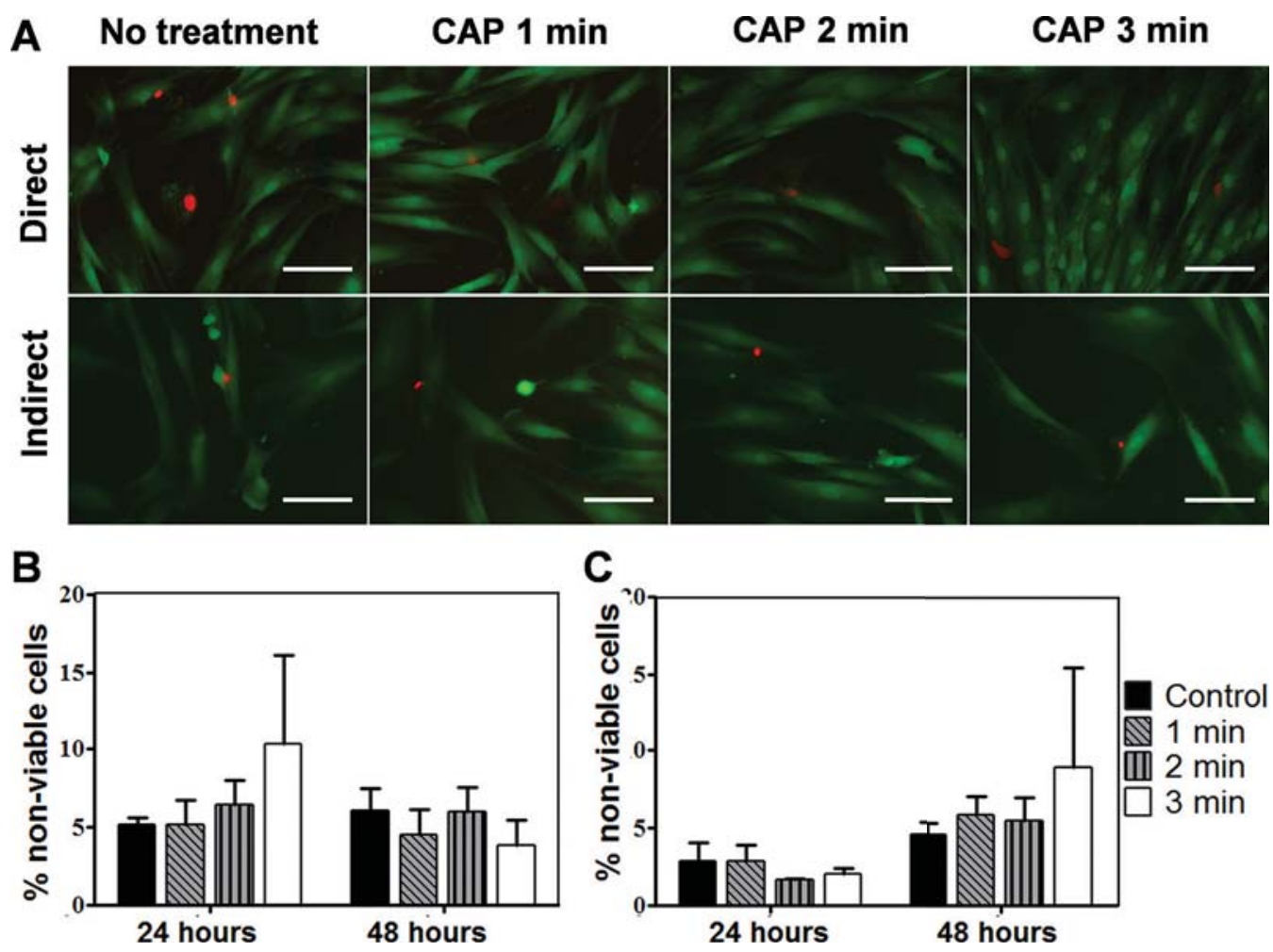

FIG. 4: LIVE/DEAD viability assay of primary fibroblasts cells treated by CAP. (A) Optical fluorescent images of primary fibroblasts at $48 \mathrm{~h}$ after plasma treatment. Cells were stained with Calcein-AM (green or darker surrounding) and ethidium (red or brighter embedded points). (B) Quantitative analysis of LIVE/DEAD cell viability at 24 and $48 \mathrm{~h}$ after direct CAP treatments. (C) Quantitative analysis of LIVE/DEAD cell viability at 24 and $48 \mathrm{~h}$ after PAM treatments. Error bars represent the SEM of three measurements. Scale, $100 \mu \mathrm{m}$. CAP, Cold-atmospheric plasma.

plasma treatment in $2 \mathrm{~mL}$ of PBS (Table 1). Indeed, for all studied cells, $1 \mathrm{~min}$ of treatment with plasma led to an accelerated migration rate. These species were tested separately and mixed (with the treatment called "mix"). The chemical composition of the mix (chemical compounds dissolved in water) was similar to that of PAM. It was found that none of these long-lived species, alone or together, had an effect on cell migration [Fig. 7(C),(F),(I)]. Taken together, these results could mean that short-lived species and possibly pulsed electric field were responsible for boosting scratch wound closures for the three cell lines studied, because only direct treatment impacts migration.

\section{Wound Closure In Vivo}

The effect of plasma jet was tested on an acute full-thickness, excisional, mouse wound model (Fig. 8). In the following experiments, working parameters were set to $V=24$ 

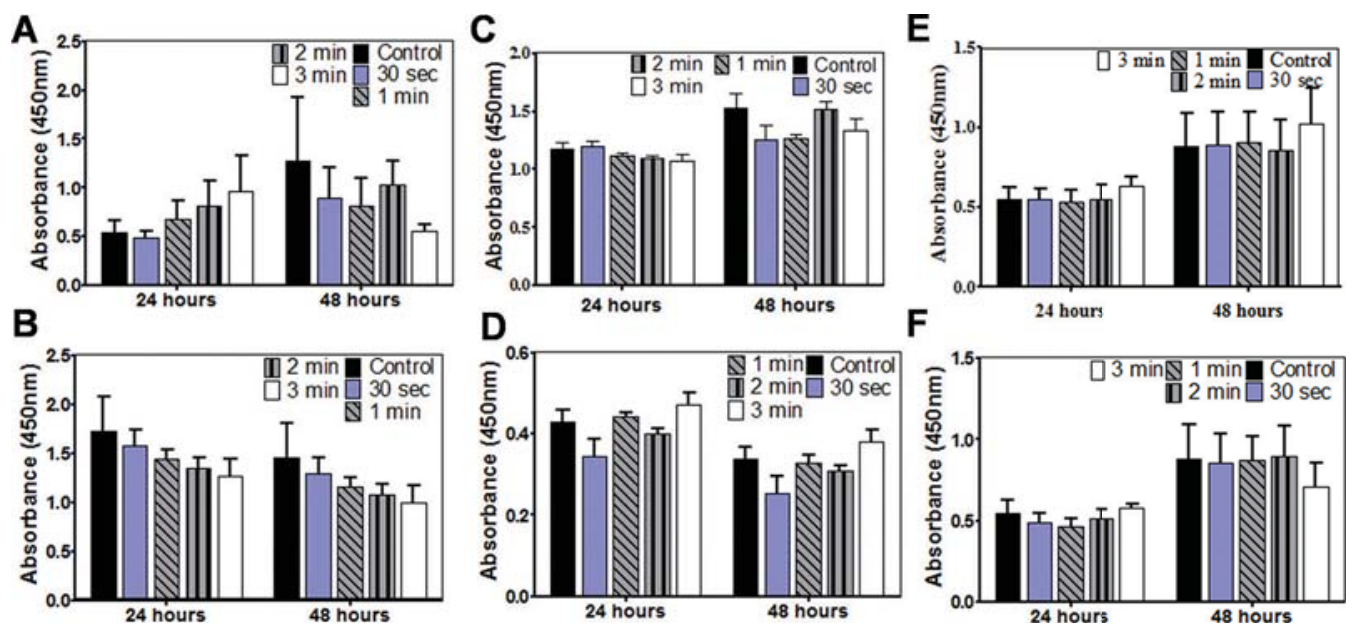

FIG. 5: Effect of plasma treatment on skin cell viability and proliferation using WST-1 assay. (A) Effect of direct treatment on keratinocytes. (B) Effect of PAM on keratinocytes. (C) Effect of direct treatment on endothelial cells. (D) Effect of PAM on endothelial cells. (E) Effect of direct treatment on fibroblasts. (F) Effect of PAM on fibroblasts.

$\mathrm{kV}$, helium mass flow $=500 \mathrm{sccm}$, and distance between mice skin and plasma source was between 7 and $10 \mathrm{~mm}$. Despite the lack of effect of PAM in vitro, indirect treatment was tested on wound healing to enable comparison to direct treatment. When direct treatment was performed, two different treatment times and frequencies were studied, leading to four different treatment conditions.

Healing of the full-thickness wound is represented in Figs. 9 and 10 for indirect and direct treatment, respectively. First, we quantitatively measured the wound area using digital photos. Direct plasma treatment did not accelerate wound closure during the $3 \mathrm{~d}$ of wound-size measurement (Fig. 10). Direct plasma treatments of $10 \mathrm{~s}$ (once or three times) and $30 \mathrm{~s}$ (once) had no significant positive or negative effect on wound closure. However, direct treatment of $30 \mathrm{~s}$ that was repeated every $48 \mathrm{~h}$ significantly decreased the wound closure rate $1 \mathrm{wk}$ after wound induction. All wound specimens were subjected to histological analysis at day 7, with histological wound size measured after H\&E staining. No significant difference was found between histological wound sizes at day 7 of the wound treated with PAM compared to that of the wound treated with PBS [Fig. 9(D)]. Thus, neither direct nor indirect treatment was efficacious for accelerating wound healing in this model of full-thickness wounds.

\section{DISCUSSION}

To determine the plasma energy threshold leading to cell damage and death, different treatment times were tested. Experiments were performed with keratinocytes, primary fibroblasts, and endothelial cells. After direct plasma treatment of cells in complete 

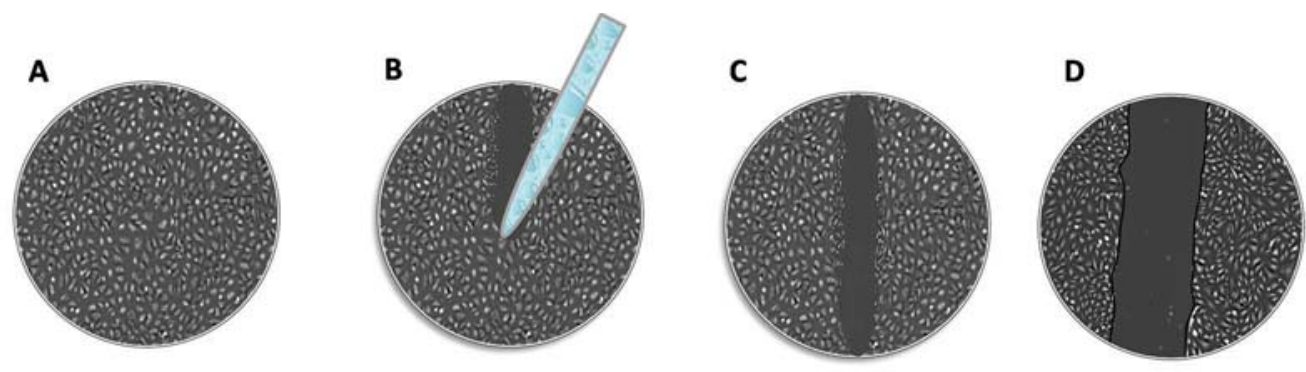

\section{E No treatment}

CAP 1 min
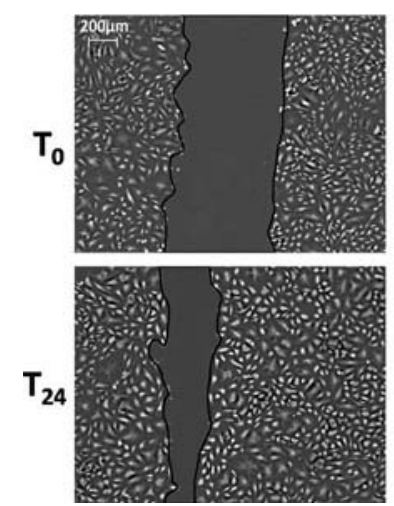

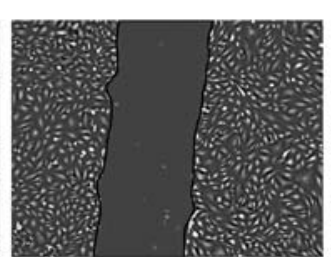

CAP 2 min
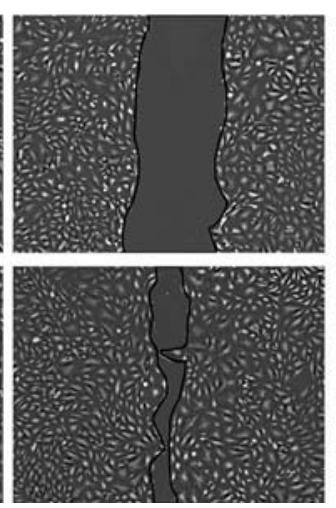

CAP 3 min
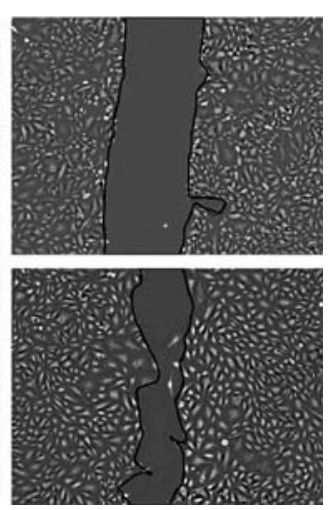

FIG. 6: In vitro scratch wound healing assay method. (A) Cells were seeded in a 24-well plate and allowed to grow to $90 \%$ confluence. (B) A scratch was mechanically done in the middle of the well with a $1-\mathrm{mL}$ tip. (C) Treatment was performed 0 and $24 \mathrm{~h}$ after the scratch was performed. (D) Photos were taken at 0,24, and $48 \mathrm{~h}$ after the scratch. At different time points, the gap area was evaluated with ImageJ software. (E) Representative images show effect of direct plasma treatment on HMVEC migration. The scale bar is equivalent in all images. CAP, Cold-atmospheric plasma.

culture media, cell viability declined depending on treatment time. For 1 and 2 min of plasma treatment, cells showed a small mortality rate with no significant difference in comparison to the control. However, cells treated with direct CAP for 3 min showed signs of cellular damage and a mortality rate that was significantly higher than that of the control. A significant increase in cellular damage was recorded $24 \mathrm{~h}$ after direct CAP treatment, with the number of dead keratinocytes doubling following treatment ( $3 \mathrm{~min}$ ) in comparison to that of untreated controls. These results show that the effect of plasma on cell viability is time dependent and that treatment time $>3$ min should be avoided (see Table 1 for the corresponding values of deposited plasma energy and production of RONS). For endothelial cells, 3-min treatment caused the death of $35 \%$ of cells versus $10 \%$ in controls. This means that endothelial cells are more sensitive to direct plasma treatment than fibroblasts and keratinocytes, and the effect of plasma also 

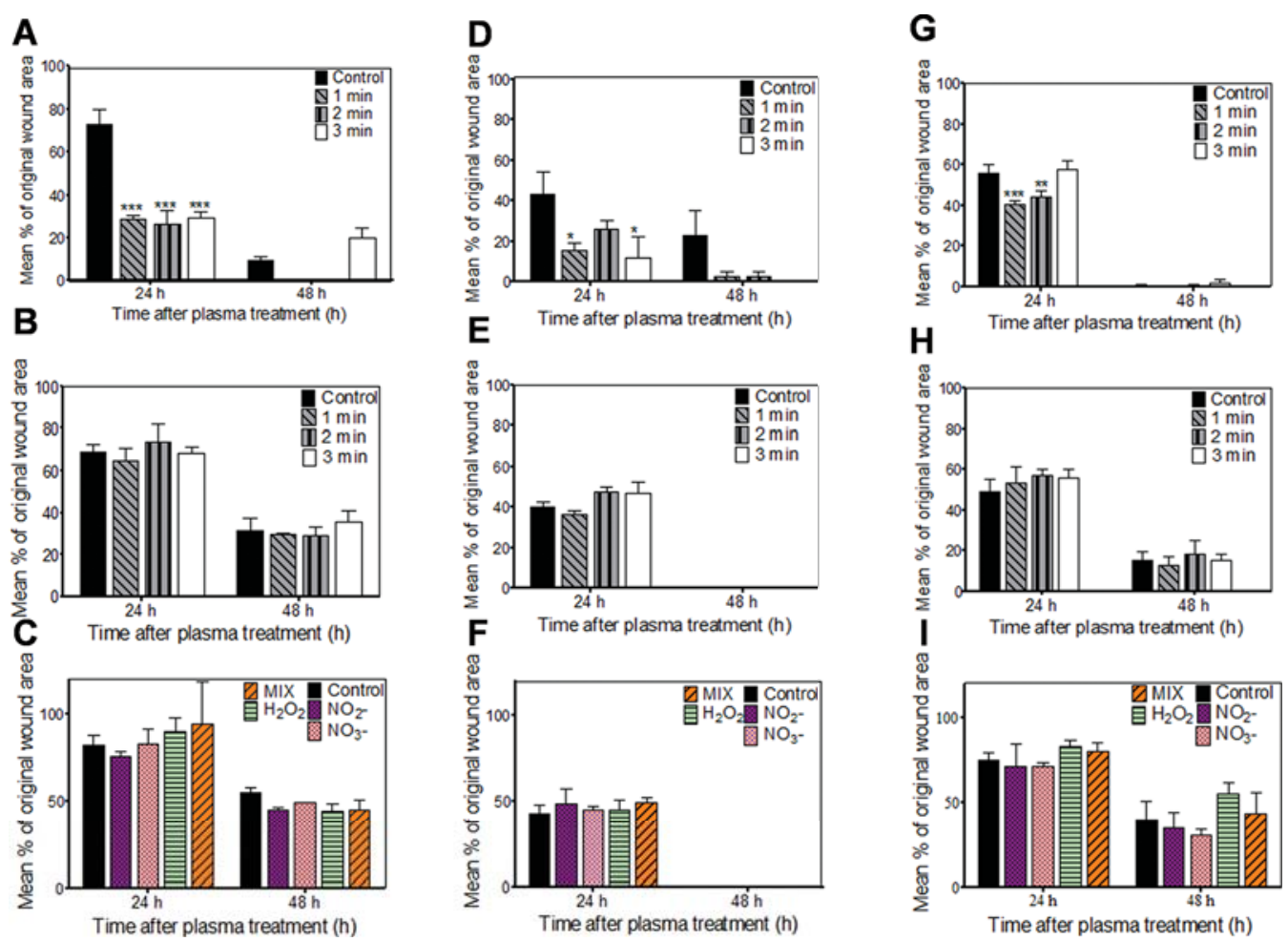

FIG. 7: Quantitative analyses of the migration assays are expressed as percentages relative to untreated cells (control is set at 100\%). Data represent the mean of three experiments $+/$ - SEM. ${ }^{*} p<0.05$ versus corresponding untreated control group. (A),(D),(G) Results of the wound healing assay with two direct treatments (at 0 and $24 \mathrm{~h}$ after the scratch) with CAP for HaCaT (A), HMVEC (D), and primary fibroblasts $(\mathrm{G}) .(\mathrm{B}),(\mathrm{E}),(\mathrm{H})$ Results of wound healing assay with two indirect treatments (at 0 and $24 \mathrm{~h}$ after the scratch) using PAM for HaCaT (B), HMVEC (E), and primary fibroblasts (H). (C),(F),(I) Results of wound healing assay with two treatments (at 0 and $24 \mathrm{~h}$ after the scratch) using long-life species alone or together at a concentration corresponding to 1 min of CAP treatment for HaCaT (C), HMVEC (F), and primary fibroblasts (I).

depends on cell type. Susceptibility of endothelial cells to plasma was also shown by Arndt et al. ${ }^{33}$ The fact that plasma toxicity is time and power dependent was described by other researchers in a variety of cell types, including fibroblasts, ${ }^{32,39,40,41}$ keratinocytes, ${ }^{40-42,44}$ and endothelial cells. ${ }^{33-45}$ However, the power of the plasma source was not always provided in previous publications, so it is not always possible to compare the cell-damage threshold in terms of produced energy and/or equivalent production of ROS. Kang et al. showed that their plasma jet damaged fibroblasts and keratinocytes after 1 min of treatment, but energy delivered to the cells was not provided. ${ }^{32}$ Treatment with MicroPlaSter $\beta$, used by Maisch et al., induced a significant decrease in keratinocyte and fibroblast viability after 5 min of treatment, whereas mortality did not significantly increase after 1 and 2 min of treatment. ${ }^{33,40}$ Interestingly, repeating 

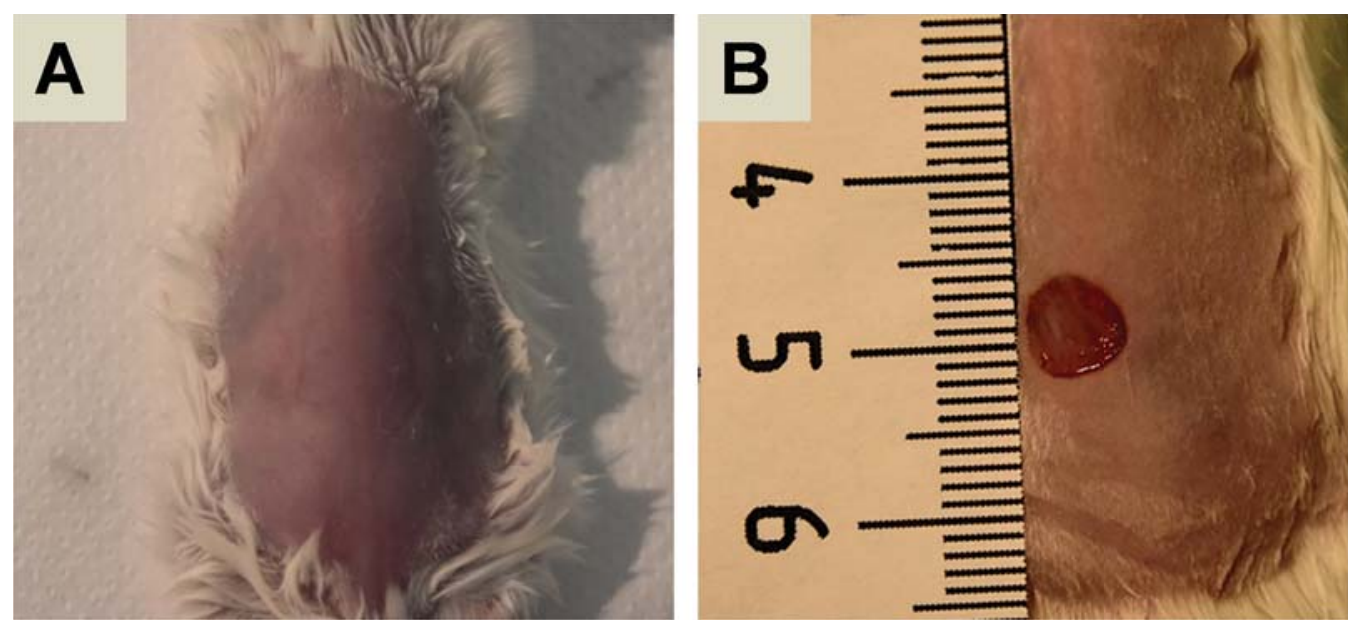

FIG. 8: Stepwise skin excisional wound in surgery. (A) Mice were shaved, and all remaining hairs were removed with depilatory cream; (B) a 6-mm-diameter wound is made with 6-mm-diameter biopsy punch.

treatment every $24 \mathrm{~h}$ did not increase mortality during a period of $72 \mathrm{~h}$. This plasma source used higher power than was used in this study, and distance of source from target was four times farther away. The effect of plasma treatment time on endothelial cell viability was studied by Suzuki and Yoshino. ${ }^{45}$ These investigators used micropower dielectric barrier discharge (DBD) as the power and $\mathrm{H}_{2} \mathrm{O}_{2}$ concentration that was similar to what were used in the current study: $0.018 \mathrm{~W}$ and $15 \mu \mathrm{M}$ for treatment of $2 \mathrm{~min}$ (in our study, $0.09 \mathrm{~W}$ and $14 \mu \mathrm{M}$ for $2 \mathrm{~min}$ ). Suzuki and Yoshino found cells to be damaged after 5 min of treatment. ${ }^{45}$ An ex vivo study performed by Hasse et al. on human patient skin samples using kinPenMed (Neoplas GmbH, Greifswald, Germany), showed that the number of apoptotic cells increased with treatment time, and a significant increase in mortality occurred at 5 min. ${ }^{44}$

Mortality that is induced by plasma is commonly associated with oxidative and nitrosative stress due to different active ROS and RNS that are produced by plasma in liquids ${ }^{46}$ In fact, multiple studies have shown that plasma treatment induced increase in intracellular ROS concentration in treated cells, with the increase proportional to treatment time. ${ }^{39,41,42,45}$ Kalghatgi et al. reported that nonthermal DBD plasma generated ROS, such as superoxide anions, hydrogen peroxide, hydroxyl radicals, single oxygen, and ozone. ${ }^{47}$ Cui et al. reduced cell mortality after plasma treatment by adding $N$ acetylcysteine, an antioxidant and ROS scavenger molecule. ${ }^{39}$ This clearly shows that oxidative stress induced by plasma is involved in cell mortality. In the present study, $\mathrm{H}_{2} \mathrm{O}_{2}$ that was produced by plasma measured $\sim 10 \mu \mathrm{M}$. We checked to ensure that this concentration of $\mathrm{H}_{2} \mathrm{O}_{2}$ added alone to the cell media (without plasma treatment) did not induce significant damage to cells. Suzuki and Yoshino showed that intracellular ROS concentration was three times higher after plasma treatment than after $\mathrm{H}_{2} \mathrm{O}_{2}$ was added

Volume 8, Issue 4, 2018 

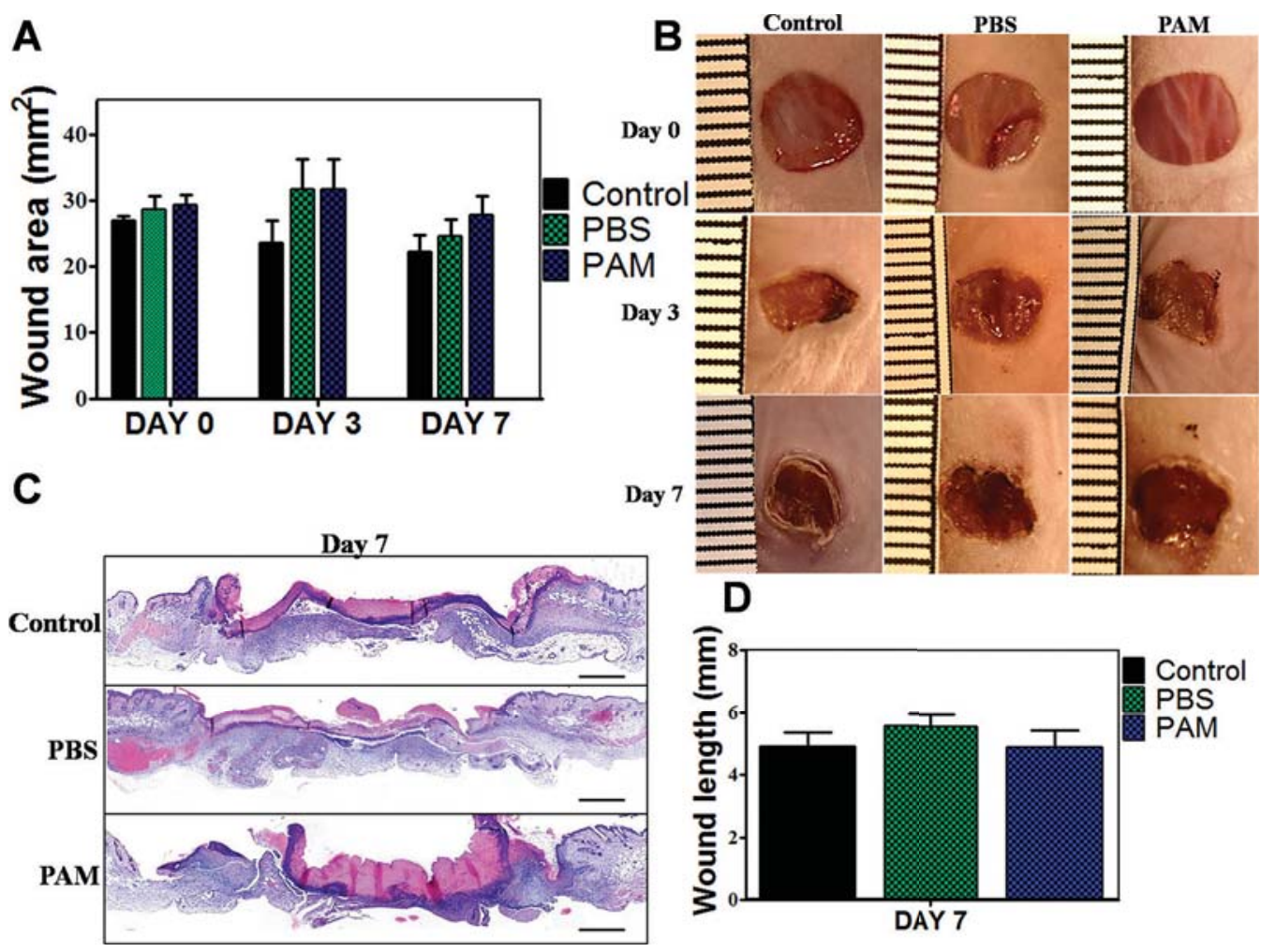

FIG. 9: Dermal full-thickness wound treated with PAM. (A) Quantification of wound area at days 0,3 , and 7 after wound induction. (B) Representative photographs of wounds treated with control, PBS injection, and PAM injection at days 0,3 , and 7 after wound induction. (C) Representative image of dermal full-thickness wound with H\&E staining. (D) Quantification of wound length at day 7 for different treatments. Statistical analysis was performed using unpaired $t$-tests. Data are represented as mean $+\operatorname{SEM}\left({ }^{*} p<0.05\right)$ for $n=$ Scale bar, $100 \mu \mathrm{m}$. PAM, Plasmaactivated media; PBS, phosphate-buffered saline.

to media. ${ }^{45}$ This shows how mortality induced by plasmas can be triggered by ROS chemicals other than $\mathrm{H}_{2} \mathrm{O}_{2}$ with a short half life, such as $\mathrm{O}_{2}^{-}, \mathrm{OH}$, or physical factors such as electromagnetic field.

For the three cell lines studied, indirect treatment (PAM) showed no toxicity even after 3 min of treatment, corresponding to $6.5 \mathrm{~J} / \mathrm{cm}^{3}$ and a $\mathrm{H}_{2} \mathrm{O}_{2}$ concentration of $15 \mu \mathrm{M}$. To our knowledge, a few publications have addressed cytotoxic effects of PAM. One study investigated the effect of PAM on keratinocytes using the kinPen09 (Neoplas $\mathrm{GmbH}$ ), showing that the CAP-induced tendency for apoptosis failed to reach significance. ${ }^{48}$ In another work, Girard et al. studied the effect of $\mathrm{H}_{2} \mathrm{O}_{2}$ on normal human skin fibroblasts and found that this molecule had a central role in the cellular cytotoxic effect of plasma ${ }^{49}$ However, the concentration in this study was $\sim 1 \mathrm{~mm}$ or 100 times higher than that used in the current study. ${ }^{49}$ 

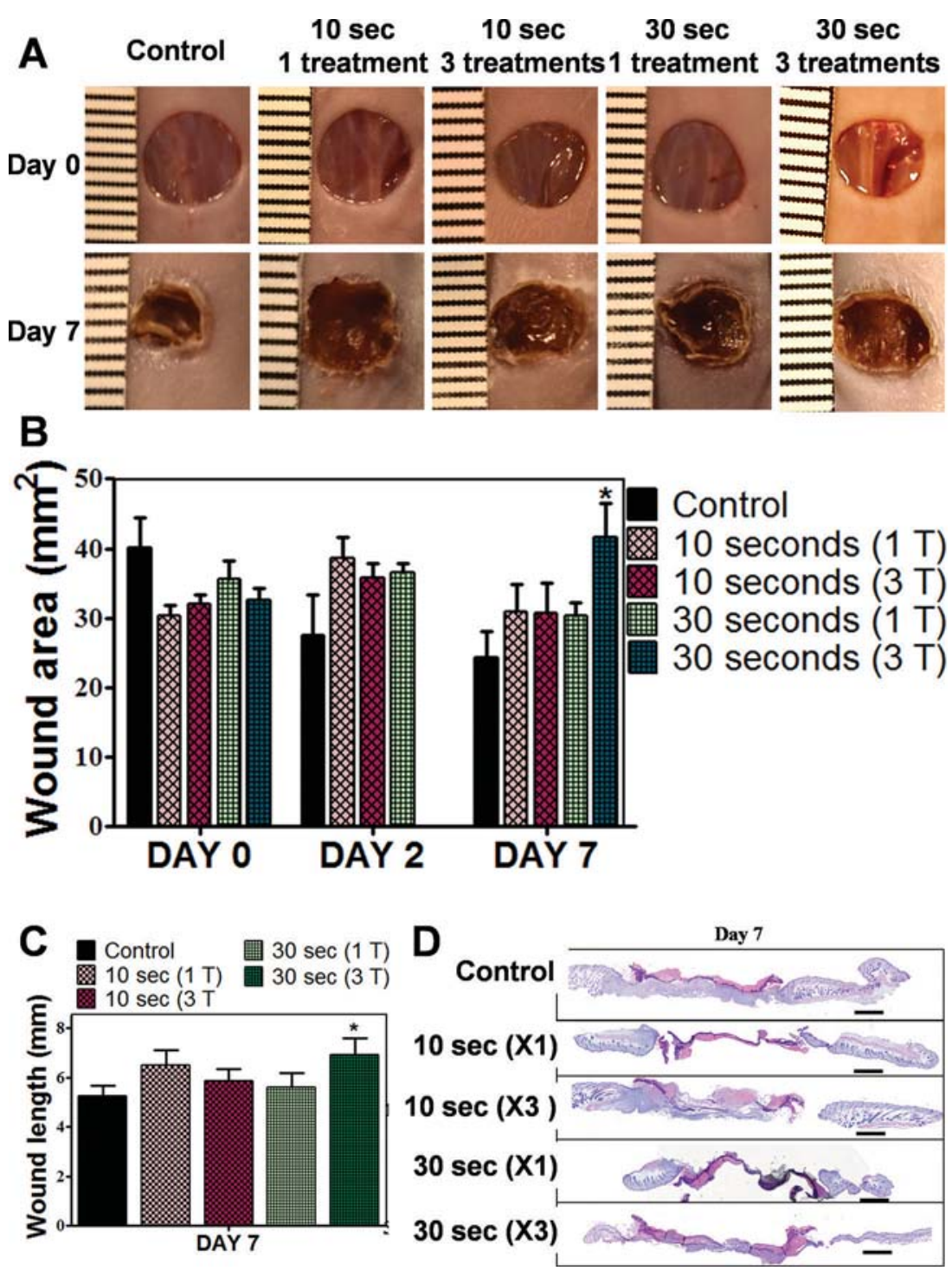

FIG. 10: Dermal full-thickness wound treated with direct CAP treatment. (A) Representative photographs of wounds at days 0 and 7 after wound induction. (B) Quantification of wound area at days 0,2 , and 7 after wound induction. (C) Quantification of wound length at day 7 for different treatments. (D) Representative image of dermal full-thickness wound with H\&E staining. Statistical analysis was performed using unpaired $t$-tests. Data are represented as mean + SEM $\left({ }^{*} p<0.05\right)$ for $n=$ Scale bar, $100 \mu \mathrm{m}$.

In this work, we found that cellular proliferation was not enhanced after both indirect and direct plasma treatment. Arndt et al. showed similar results for 2 min of treatment with the MicroPlaSter $\beta .{ }^{28}$ Indeed, these authors showed that keratinocyte proliferation 
was not stimulated, both in vitro and in vivo. ${ }^{28}$ Regarding cell migration, we found that plasma treatment enhanced cellular migration with a scratch assay test. Taken together with proliferation experiments, the results suggest that enhanced scratch wound closure seen in cellular monolayers that are treated with plasma jet are mostly due to stimulated migration rather than proliferation. Although a 2.5 -fold decrease in keratinocyte and endothelial cell scratch wound size occurred following direct plasma treatment (1 and $2 \mathrm{~min}$ ), no significant difference in scratch wound size was observed in fibroblasts treated for $2 \mathrm{~min}$.

These results suggest that stimulation of migration by direct plasma treatment, as well as toxic effects, are cell type and treatment time dependent. Interestingly, our study also showed that only direct CAP treatment induced cellular migration in vitro, whereas indirect treatment with PAM had no effect. To our knowledge, the effect of PAM on cellular migration has not been studied before, and our study endeavored to compare the effect of direct plasma treatment and PAM treatment on cellular migration. Previous studies reported that plasma treatment enhanced cellular migration, and some studies described an optimum treatment time that induced a positive effect on cellular migration. Optimum treatment time found in the current study using a homemade helium plasma jet was $1 \mathrm{~min}$ for the three cell types studied. In similar studies reported in the literature, optimum treatment time varied from $10 \mathrm{~s}$ to $5 \mathrm{~min}$, because plasma devices differed, as did treatment conditions (volume treated and frequency). ${ }^{10,28,30,32,33,39}$ Significant enhancement of endothelial cell migration was shown by Arjunan and Clyne using treatment using DBD with measured energy of $4.2 \mathrm{~J} / \mathrm{cm}^{2} .^{30}$ This energy was similar to that used in the current study (see Table 1), although treated volume was smaller (2 vs $\left.0.1 \mathrm{~cm}^{3}\right)$. Using the MicroPlaSter $\beta$ plasma torch, Arndt et al. found that $30 \mathrm{~s}$ of plasma treatment enhanced endothelial cell and fibroblast migration and proliferation, whereas greater treatment time led to cell damage. ${ }^{28,33}$ Surprisingly, some negative effects of helium and argon plasma jets on fibroblast migration were also shown by Kang et al., even if energy was not high enough to produce cytotoxic effects on cells. ${ }^{32}$

ROS and RNS have essential roles in skin aging, tissue repair, and wound closure. ${ }^{50-52}$ They both act as secondary messengers and are used by cells including platelets, macrophages, endothelials, fibroblasts, and keratinocytes. ${ }^{53}$ ROS and RON are also known to regulate angiogenesis at the wound site as well as vascular vasoconstriction and relaxation to ensure optimal perfusion of blood into the wound healing area. This explains the hypothesis that ROS and RNS that are produced by plasma are responsible for plasma effects observed by numerous teams studying these effects in vitro and in vivo. However, in this study, the effects of long-life ROS and RNS that were produced by plasma on cell migration were also tested, and like PAM, they produced no significant effect. Thus, it can be assumed that only short-lived species and/or electric field are implied in induction of cell migration by plasma. Here, NO may play a major part. This molecule is produced by cells with the aid of NO synthase and has various physiological effects during wound healing. ${ }^{37}$ Indeed, this small radical regulates extracellular matrix synthesis, cell proliferation, reepithilialization, and angiogenesis. ${ }^{30,37,54} \mathrm{NO}$ is also produced by CAP, and its intracellular concentration increases with CAP treatment. ${ }^{55-57}$ 
Cell adhesion also has a critical role in cell migration during wound healing. To ensure that CAP had a direct influence on cells, and stimulation of cell migration was not due to modification of the plate, we performed surface testing (results not shown). No effect was found on cellular migration in response to pretreatment of culture plates.

Treatment of mouse wounds with direct and indirect plasma showed no significant difference in wound healing in vivo. The macroscopic size of wounds treated with PAM was larger than in untreated controls, but given that the size of wounds treated with PBS was also slightly larger than that of untreated controls, this negative effect may have been due to local skin injury that was induced by intradermal injection rather than the effect of plasma. Macroscopic and microscopic mouse wound size remained unchanged in response to direct CAP treatment. Although previous studies have shown that plasma is associated with accelerated wound healing, ${ }^{16,31,32,58-60}$ it must be pointed out that both plasma devices and treatment parameters were different from those used in the current study, which could explain the difference in results. Moreover, in these studies complete healing time is not significantly changed by plasma treatment. In most of these, if the wound area was diminished with CAP treatment, the reduction was verified only for a few times points and sometimes not even linked together in the time line. For example, wound area size was significantly different only for $1 \mathrm{~d}$ of 14 in Kubinova et al..$^{58}$ and Kang et al. ${ }^{32}$ studies and for $2 \mathrm{~d}$ of 14 in an Arndt et al. study. ${ }^{31}$ The most significant effect was obtained by Nasruddina et al., who showed $5 \mathrm{~d}$ of $14 .{ }^{16}$ But surprisingly, in this study these five significant days were not sequential. ${ }^{16,31,32,58,59}$ Taken together, results suggest that the benefits of plasma on acute wound healing may be limited.

The current study suggests that exposure time is critical and even at low power, plasma treatment may have a detrimental effect on wound healing, as was the case with wounds treated with a direct plasma jet for $30 \mathrm{~s}$ every $48 \mathrm{~h}$. In vivo, applied energy was $\sim 0.1 \mathrm{~J}$ or 50 times less than energy in the in vitro study. However, this may have caused cell damage in vivo due to the absence of protective layer that is created by media. One hypothesis is that in vitro, some species produced by plasma react directly with the media, producing different molecules, especially short-life species that will react immediately with amino acids and proteins in the media, leading to production of new long-life reactive species. This explains why dose-related effects were not reproducible from cells to the mouse model. Xu et al. also showed that an overdose of plasma suppressed wound healing in vivo in comparison to the control, due to tissue necrosis and cellular apoptosis. ${ }^{61}$

\section{CONCLUSION}

This work investigated the effects of a homemade plasma jet on wound healing and cellular viability, both in vitro and in vivo. It enabled comparison between two types of treatment, namely, direct treatment with CAP and indirect treatment with PAM. This study provides evidence that a short and direct application of 1 min of CAP does not cause cell death and improves cellular migration in vitro. However, PAM does not affect migration in the same way as direct treatment. Using an acute wound model in mice, the

Volume 8, Issue 4, 2018 
effect of PAM and direct treatment were tested in three groups of six mice. In the case of plasma treatment, $\sim 0.1 \mathrm{~J}$ was applied on days 0,2 , and Similarly, $2.2 \mathrm{~J} / \mathrm{cm}^{3}$ of PAM solution was injected at wound boundaries on days 0,2 , and no significant difference was recorded in response to direct and indirect plasma treatment. Further studies are required to establish the underlying cellular and molecular pathways that are responsible for biological changes induced by CAP.

\section{ACKNOWEDGMENTS}

This work was supported by La Direction Générale de L'Armement and École Polytechnique. We thank Maryline Favier and Rachel Onifarasoaniaina of Institut Cochin for sample preparation and consultation. The authors thank Dr. Bruno Honnorat of École Polytechnique for his expertise and helpful advice.

\section{REFERENCES}

1. Gurtner GC, Werner S, Barrandon Y, Longaker MT. Wound repair and regeneration. Nature. 2008 May 15;453:314-21.

2. Vig K, Chaudhari A, Tripathi S, Dixit S, Sahu R, Pillai S, Dennis VA, Singh SR. Advances in skin regeneration using tissue engineering. Int J Mol Sci. 2017 Apr 7;18(4):789.

3. Wu Y, Chen L, Scott PG, Tredget EE. Mesenchymal stem cells enhance wound healing through differentiation and angiogenesis. Stem Cells. 2007 Oct 25;25:2648-59.

4. Lieberman MA, Lichetenberg AJ. Principles of plasma discharges and materials processing. 2nd edition. New York: John Wiley \& Sons; 2005.

5. Daeschlein G, Napp M, Lutze S, Arnold A, von Podewils S, Guembel D, Junger M. Skin and wound decontamination of multidrug-resistant bacteria by cold atmospheric plasma coagulation. J Dtsch Dermatol Ges. 2015 Feb;13(2):143-50.

6. Ermolaeva SA, Varfolomeev AF, Chernukha MY, Yurov DS, Vasiliev MM, Kaminskaya AA, Moisenovich MM, Romanova JM, Murashev AN, Selezneva II, Shimizu T, Sysolyatina EV, Shaginyan IA, Petrov OF, Mayevsky EI, Fortov VE, Morfill GE, Naroditsky BS, Gintsburg AL. Bactericidal effects of non-thermal argon plasma in vitro, in biofilms and in the animal model of infected wounds. J Med Microbiol. 2011 Aug;60(Pt 1):75-83.

7. Mohd Nasir N, Lee BK, Yap SS, Thong KL, Yap SL. Cold plasma inactivation of chronic wound bacteria. Arch Biochem Biophys. 2016 Sept 1;605:76-85.

8. Klampfl TG, Isbary G, Shimizu T, Li YF, Zimmermann JL, Stolz W, Schelegel J, Morfill GE, Schmidt HU. Cold atmospheric air plasma sterilization against spores and other microorganisms of clinical interest. Appl Environ Microbiol. 2012 Aug;78(15):5077-82.

9. Chatraie M, Torkaman G, Khani M, Salehi H, Shokri B. In vivo study of non-invasive effects of nonthermal plasma in pressure ulcer treatment. Sci Rep. 2018 Apr 4;8(1):5621.

10. Schmidt A, Bekeschus S, Wende K, Vollmar B, von Woedtke T. A cold plasma jet accelerates wound healing in a murine model of full-thickness skin wounds. Exp Dermatol. 2017 Feb;26(2):156-62.

11. Isbary G, Heinlin J, Shimizu T, Zimmermann JL, Morfill G, Schmidt HU, Monetti R, Steffes B, Bunk W, Li Y, Klaempfl T, Karrer S, Landthaler M, Stolz W. Successful and safe use of 2 min cold atmospheric argon plasma in chronic wounds: Results of a randomized controlled trial. Br J Dermatol. 2012 Aug;167(2):404-10.

12. Heinlin J, Morfill G, Landthaler M, Stolz W, Isbary G, Zimmermann JL, Shimizu T, Karrer S. Plasma medicine: Possible applications in dermatology. J Dtsch Dermatol Ges. 2010 Dec;8(12):968-76. 
13. Duval A, Marinov I, Bousquet G, Gapihan G, Starikovskaia SM, Rousseau A, Janin A. Cell death induced on cell cultures and nude mouse skin by non-thermal, nanosecond-pulsed generated plasma. PLoS One. 2013;8(12):e83001.

14. Kang SU, Cho JH, Chang JW, Shin YS, Kim KI, Park JK, Yang SS, Lee JS, Moon E, Lee K, Kim CH. Nonthermal plasma induces head and neck cancer cell death: The potential involvement of mitogenactivated protein kinase-dependent mitochondrial reactive oxygen species. Cell Death Dis. 2014 Feb 13;5:1056.

15. Vandamme M, Robert E, Lerondel S, Sarron V, Ries D, Dozias S, Sobilo J, Gosset D, Kieda C, Legrain B, Pouvesle JM, Pape AL. ROS implication in a new antitumor strategy based on non-thermal plasma. Int J Cancer. 2012 May 1;130(9):2185-94.

16. Nasruddina YN, Kanae M, Heni S, Rahayu E, Nur M, Ishijima T, Enomotod H, Uesugi Y, Sugama J, Nakatani T. Cold plasma on full-thickness cutaneous wound accelerates healing through promoting inflammation, re-epithelialization and wound contraction. Clin Plas Med. 2014;2:28-35.

17. O'Connor N, Cahill O, Daniels S, Galvin S, Humphreys H. Cold atmospheric pressure plasma and decontamination. Can it contribute to preventing hospital-acquired infections? J Hosp Infect. 2014 Oct;88(2):59-65.

18. Cahill OJ, Claro T, O’Connor N, Cafolla AA, Stevens NT, Daniels S, Humphreys H. Cold air plasma to decontaminate inanimate surfaces of the hospital environment. Appl Environ Microbiol. 2014 Mar;80(6):2004-10.

19. Betancourt-Angeles M, Pena-Eguiluz R, Lopez-Callejas R, Dominguez-Cadena NA, Mercado-Cabrera A, Munoz-Infante J, Rodriguez-Mendez BG, Valencia-Alvarado R, Moreno-Tapia JA. Treatment in the healing of burns with a cold plasma source. Int J Burn Trauma. 2017;7(7):142-6.

20. Daeschlein G, Scholz S, Ahmed R, von Woedtke T, Haase H, Niggemeier M, Kindel E, Brandenburg $\mathrm{R}$, Weltmann KD, Juenger M. Skin decontamination by low-temperature atmospheric pressure plasma jet and dielectric barrier discharge plasma. J Hosp Infect. 2012 Jul;81(3):177-83.

21. Ulrich C, Kluschke F, Patzelt A, Vandersee S, Czaika VA, Richter H, Bob A, Hutten JV, Painsi C, Huge R, Kramer A, Assadian O, Lademann J, Lange-Asschenfeldt B. Clinical use of cold atmospheric pressure argon plasma in chronic leg ulcers: A pilot study. J Wound Care. 2015 May;24(5):196, 198-200, 202-3.

22. Emmert SBF, Hänßle H, Helmke A, Mertens N, Ahmed R, Simon D, Wandke D, Maus-Friedrichs W, Däschlein G, Schön MP, Viöl W. Atmospheric pressure plasma in dermatology: Ulcus treatment and much more. Clin Plas Med. 2013;1:24-9.

23. Klebes M, Lademann J, Philipp S, Ulrich C, Patzelt A, Ulmer M, Kluschke F, Kramer A, Weltmann $\mathrm{KD}$, Sterry W, Asschenfeldt B. Effects of tissue-tolerable plasma on psoriasis vulgaris treatment compared to conventional local treatment: A pilot study. Clin Plas Med. 2014; 2(1):22-7.

24. Daeschlein G, Scholz S, Ahmed R, Majumdar A, von Woedtke T, Haase H, Nigemeier M, Kindel E, Brandenburg R, Weltmann KD, Junger M. Cold plasma is well-tolerated and does not disturb skin barrier or reduce skin moisture. J Dtsch Dermatol Ges. 2012 Jul;10(7):509-15.

25. Heinlin J, Isbary G, Stolz W, Zeman F, Landthaler M, Morfill G, Shimizu T, Zimmermann JL, Karrer S. A randomized two-sided placebo-controlled study on the efficacy and safety of atmospheric nonthermal argon plasma for pruritus. J Eur Acad Dermatol Venereol. 2013 Mar;27(3):324-31.

26. Haertel B, von Woedtke T, Weltmann KD, Lindequist U. Non-thermal atmospheric-pressure plasma possible application in wound healing. Biomol Ther (Seoul). 2014;22(6):477-90.

27. Graves DB. Low temperature plasma biomedicine: A tutorial review. Phys Plasma. 2014 Nov;21(8): 080901-080901.12.

28. Arndt S, Landthaler M, Zimmermann JL, Unger P, Wacker E, Shimizu T, Li YF, Morfill GE, Bosserhoff AK, Karrer S. Effects of cold atmospheric plasma (CAP) on $\beta$-defensins, inflammatory cytokines, and apoptosis-related molecules in keratinocytes in vitro and in vivo. PLoS One. 2015;10(3):e0120041.

29. Fridman G, Gutsol A, Shekhter AB, Vasilets VN, Fridman A. Applied plasma medicine. Plasma Proc Polym. 2008;5(6):503-33.

Volume 8, Issue 4, 2018 
30. Arjunan KP, Clyne AM. Non-thermal dielectric barrier discharge plasma induces angiogenesis through reactive oxygen species. J Roy Soc Interface. 2012; 9(66):147-57.

31. Arndt S, Unger P, Wacker E, Shimizu T, Heinlin J, Li YF, Thomas HM, Morfill GE, Zimmermann JL, Bosserhoff AK, Karrer S. Cold atmospheric plasma (CAP) changes gene expression of key molecules of the wound healing machinery and improves wound healing in vitro and in vivo. PLoS One. 2013;8(11):e79325.

32. Kang SU, Choi JW, Chang JW, Kim KI, Kim YS, Park JK, Kim YE, Lee YS, Yang SS, Kim CH. $\mathrm{N}_{2}$ Non-thermal atmospheric pressure plasma promotes wound healing in vitro and in vivo: Potential modulation of adhesion molecules and matrix metalloproteinase-9. Exp Dermatol. 2017 Feb;26(2):163-70.

33. Arndt S, Unger P, Berneburg M, Bosserhoff AK, Karrer S. Cold atmospheric plasma (CAP) activates angiogenesis-related molecules in skin keratinocytes, fibroblasts and endothelial cells and improves wound angiogenesis in an autocrine and paracrine mode. J Dermatol Sci. 2018 Feb;89(2):181-90.

34. Violleau F, Hadjeba K, Albet J, Cazalis R, Surel O. Effect of oxidative treatment on corn seed germination kinetics. Ozone-Sci Eng. 2015;30:418-22.

35. Bailly C. Active oxygen species and antioxidants in seed biology. Seed Sci Res. 2004;14:97-107.

36. Mone Y, Monnin D, Kremer N. The oxidative environment: A mediator of interspecies communication that drives symbiosis evolution. Proc Biol Sci. 2014 Jun 22;281(1785):20133112.

37. Stallmeyer B, Kampfer H, Kolb N, Pfeilschifter J, Frank S. The function of nitric oxide in wound repair: Inhibition of inducible nitric oxide-synthase severely impairs wound reepithelialization. J Invest Dermatol. 1999 Dec;113(6):1090-8.

38. Luo JD, Chen AF. Nitric oxide: A newly discovered function on wound healing. Acta Pharmacol Sin. 2005 Mar;26(3):259-64.

39. Cui HS, Joo SY, Lee DH, Yu JH, Jeong JH, Kim JB, Seo CH. Low temperature plasma induces angiogenic growth factor via up-regulating hypoxia-inducible factor $1 \alpha$ in human dermal fibroblasts. Arch Biochem Biophys. 2017 Sep 15;630:9-17.

40. Maisch T, Bosserhoff AK, Unger P, Heider J, Shimizu T, Zimmermann JL, Morfill GE, Landthaler M, Karrer S. Investigation of toxicity and mutagenicity of cold atmospheric argon plasma. Environ Mol Mutagen. 2017 Apr;58(3):172-7.

41. Lee JH, Kim KN. Effects of a nonthermal atmospheric pressure plasma jet on human gingival fibroblasts for biomedical application. Biomed Res Int. 2016;2876916:1-9.

42. Kim KC, Piao MJ, Madduma Hewage SR, Han X, Kang KA, Jo JO, Mok YS, Shin JH, Park Y, Yoo SJ, Hyun JW. Non-thermal dielectric-barrier discharge plasma damages human keratinocytes by inducing oxidative stress. Int J Mol Med. 2016 Jan;37(1):29-38.

43. Wende K, Strassenburg S, Haertel B, Harms M, Holtz S, Barton A, Masur K, von Woedtke T, Lindesquist $\mathrm{U}$. Atmospheric pressure plasma jet treatment evokes transient oxidative stress in HaCaT keratinocytes and influences cell physiology. Cell Biol Int. 2014 Apr;38(4):412-25.

44. Hasse S, Duong Tran T, Hahn O, Kindler S, Metelmann HR, von Woedtke T, Masur K. Induction of proliferation of basal epidermal keratinocytes by cold atmospheric-pressure plasma. Clin Exp Dermatol. 2016 Mar;41(2):202-9.

45. Suzuki K, Yoshino D. Proliferation-related activity in endothelial cells is enhanced by micropower plasma. BioMed Res Int. 2016;4651265:1-11.

46. Graves DB. The emerging role of reactive oxygen and nitrogen species in redox biology and some implications for plasma applications to medicine and biology. J Phys D Appl Phys. 2012;45:263001.

47. Kalghatgi S, Kelly CM, Cerchar E, Torabi B, Alekseev O, Fridman A, Friedman G, Azizkhan-Clifford J. Effects of non-thermal plasma on mammalian cells. PLoS One. 2011 Jan 21;6(1):e16270.

48. Schmidt A, von Woedtke T, Bekeschus S. Periodic exposure of keratinocytes to cold physical plasma: An in vitro model for redox-related diseases of the skin. Oxid Med Cell Longev. 2016;2016:17.

49. Girard D, Laverdet B, Buhe V, Trouillas M, Ghazi K, Alexaline MM, Egles C, Misery L, Coulomb B, Lataillade JJ, Berthod F, Ermouliere A. Biotechnological management of skin burn injuries: 
Challenges and perspectives in wound healing and sensory recovery. Tissue Eng Part B Rev. 2017 Feb;23(1):59-82.

50. Dunnill C, Patton T, Brennan J, Barrett J, Dryden M, Cooke J, Leaper D, Georgopoulos NT. Reactive oxygen species (ROS) and wound healing: The functional role of ROS and emerging ROS-modulating technologies for augmentation of the healing process. Int Wound J. 2017 Feb;14(1):89-96.

51. Loo AE, Wong YT, Ho R, Wasser M, Du T, Ng WT, Halliwell B. Effects of hydrogen peroxide on wound healing in mice in relation to oxidative damage. PLoS One. 2012;7(11):e49215.

52. Rinnerthaler M, Bischof J, Streubel MK, Trost A, Richter K. Oxidative stress in aging human skin. Biomolecules. 2015 Apr 21;5(2):545-89.

53. Soneja A, Drews M, Malinski T. Role of nitric oxide, nitroxidative and oxidative stress in wound healing. Pharmacol Rep. 2005;57(Suppl):108-19.

54. Witte MB, Barbul A. Role of nitric oxide in wound repair. Am J Surg. 2002 Apr;183(4):406-12.

55. Ngo Thi M, Shao P, Liao J, Lin CK, Yip H. Enhancement of angiogenesis and epithelialization processes in mice with burn wounds through ROS/RNS signals generated by non-thermal $\mathrm{N}_{2} /$ Ar microplasma. Plasma Proc Polym. 2014;11(11):1076-88.

56. Heuer K, Hoffmanns MA, Demir E, Baldus S, Volkmar CM, Rohle M, Furchs PC, Awakowicz P, Suschek CV, Opländer C. The topical use of non-thermal dielectric barrier discharge (DBD): Nitric oxide related effects on human skin. Nitric Oxide. 2015 Jan 30;44:52-60.

57. Kartaschew K, Mischo M, Baldus S, Brundermann E, Awakowicz P, Havenith M. Unraveling the interactions between cold atmospheric plasma and skin-components with vibrational microspectroscopy. Biointerphases. 2015 Jun 6;10(2):029516.

58. Kubinova S, Zaviskova K, Uherkova L, Zablotskii V, Churpita O, Lunov O, Dejneka A. Non-thermal air plasma promotes the healing of acute skin wounds in rats. Sci Rep. 2017 Mar 24;7:45183.

59. Hartwig S, Doll C, Voss JO, Hertel M, Preissner S, Raguse JD. Treatment of wound healing disorders of radial forearm free flap donor sites using cold atmospheric plasma: A proof of concept. J Oral Maxillofac Surg. 2017 Feb;75(2):429-35.

60. Kim HY, Kang SK, Park SM, Jung HY, Choi BH, Sim JY, Lee JK. Characterization and effects of Ar/ air microwave plasma on wound healing. Plasma Proc Polym. 2015;12(12):1423.

61. Xu GM, Shi XM, Cai JF, Chen SL, Li P, Yao CW, Chang ZS, Zhang GJ. Dual effects of atmospheric pressure plasma jet on skin wound healing of mice. Wound Rep Regen. 2015 Nov-Dec;23(6):878-84.

Volume 8, Issue 4, 2018 
